\title{
Microscopic Characters, Phytochemical Screening Focus on Alkaloid and Total Phenolic Content of Uncaria gambir Roxb. and Uncaria sclerophylla Roxb. Leaves
}

\author{
Aditya Sindu Sakti ${ }^{1}$, Fadlina Chany Saputri ${ }^{2, *}$, Abdul Mun'im ${ }^{3}$
}

\section{Aditya Sindu Sakti ${ }^{1}$, Fadlina Chany Saputri ${ }^{2, *}$, Abdul Mun'im ${ }^{3}$}

\section{'Drug Development Laboratory, Faculty of Pharmacy, Universitas Indonesia, Kampus UI Depok, 16424, West Java, INDONESIA. \\ ${ }^{2}$ Department of Pharmacology, Faculty of Pharmacy, Universitas Indonesia, Kampus UI Depok, 16424, West Java, INDONESIA.}

${ }^{3}$ Department of Phytochemistry, Faculty of Pharmacy, Universitas Indonesia, Kampus UI Depok, 16424, West Java, INDONESIA.

\section{Correspondence}

Dr. Fadlina Chany Saputri

\section{Department of Pharmacology, Faculty} of Pharmacy, Universitas Indonesia, Kampus UI Depok, 1624, West Java, INDONESIA.

Phone no : +62217270031

E-mail: fadlina.chany@farmasi.ui.ac.id

\section{History}

- Submission Date: 08-08-2018;

- Review completed: 15-10-2018;

- Accepted Date: 15-11-2018

DOI : 10.5530/pj.2019.1.20

Article Available online

http://www.phcogj.com/v11/i1

\section{Copyright}

(C) 2019 Phcog.Net. This is an openaccess article distributed under the terms of the Creative Commons Attribution 4.0 International license.

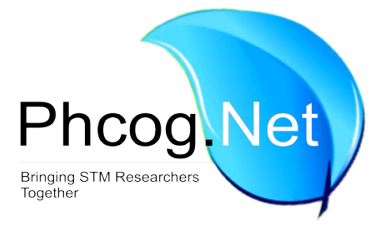

\begin{abstract}
Objective: Uncaria gambir Roxb. and Uncaria sclerophylla Roxb. are medicinal plants widely grown in Indonesia. Genus Uncaria is well known for catechin content that has potent antioxidant activity. Uncaria also was reported containing alkaloid that has antihypertensive action. This study aims to provide microscopic characters and phytochemical profiles associated with the phenolic and alkaloid compounds contained in these two species of Uncaria. Methods: Microscopic characteristics were performed on fresh leaf samples using a microscope. Presence of alkaloids from ethanol and chloroform extract of U. gambir and U. sclerophylla leaf were performed using Dragendorff reagents. Thin Layer Chromatography profile was developed in the mobile phase that consisted of acetone: chloroform (8:2). Total Phenolic Content was determined according to the Folin-Ciocalteu method using microplate reader spectroscopically at $\lambda=765 \mathrm{~nm}$. Results: Microscopy of U. gambir leaf revealed the presence of vascular bundle fragment, oil fragments, parenchyma cells, midrib transverse-section and lower epidermis with paracytic stomata. Whereas in U. sclerophylla can be observed midrib transverse-section and lower epidermis unicellular with trichomes. Both U. gambir and U. sclerophylla positively contain alkaloids. Chloroform extract showed the presence of alkaloids while ethanolic extracts showed negative results. The TLC profile shows the presence of catechin compound in the ethanolic extract, whereas in the chloroform extract does not show the presence of catechin. The total phenolic content of U. gambir and U. sclerophylla leaf ethanolic extract and chloroform extract was 7.309; 5.734 and $0.437 ; 0.161 \mathrm{mg}$ of gallic acid equivalents each gram sample, respectively. Conclusion: Microscopic characteristics, TLC and phytochemicals obtained can be used for the authentication of Uncaria gambir Roxb. and Uncaria sclerophylla Roxb leaf.

Key words: Uncaria gambir, Uncaria sclerophylla, Microscopic Characters, Phytocemical
\end{abstract} Screening, Thin Layer Chromatoghraphy, Total Phenolic Content.

\section{INTRODUCTION}

Uncaria genus has been used traditionally for various treatments such as ulcer, fever, headaches, gastrointestinal disorders, microbial infections and hypertension. ${ }^{1}$ Uncaria gambir and Uncaria sclerophylla are some medicinal plants from genus Uncaria that commonly found at Sumatra, Indonesia. ${ }^{2-4}$ Phytochemical content in the Uncaria genus leaf also has been reported have beneficial pharmacological effects on diseases such as asthma, stroke, rheumatism and several other diseases. ${ }^{5}$ Uncaria genus rich in polyphenolic compounds such as catechin. ${ }^{6}$ Catechin is a secondary metabolite which is a flavonoid compound that belongs to the flavan-3-ols group. Aqueous extract of U. gambir leaf was repoted to contain $7-76 \%$ catechin, ${ }^{6}$ that reported have antioxidant activity. ${ }^{2,7-8}$

Uncaria genus also contains Indole Alkaloids compounds which provide antihypertensive effects. ${ }^{9,10}$ The number of properties of the Uncaria genus has encouraged a number of industries to produce extracts from
Uncaria. Examination of macroscopy and microscopy chacaters, qualitative evaluation of chemical compounds and chromatographic examination are several procedure that can be applied in the quality control process of herbal raw materials. ${ }^{11}$ The macroscopy and microscopy examination of Uncaria was aimed to prevent adulteration and mistaken in the selection process of raw medicinal material from Uncaria genus. This study was aimed to provide the microscopic characters of U. gambir and U. sclerophylla leaves, total phenolic content and TLC profile of leaf extracts obtained from alkaloid and flavonoid extraction methods both of species.

\section{MATERIALS AND METHODS}

\section{Plant materials}

Uncaria gambir and Uncaria sclerophylla leaves were originally obtained from Padang, West Sumatra,
Cite this article: Sakti AS, Saputri FC, Mun'im A. Microscopic Characters, Phytochemical Screening Focus on Alkaloid and Total Phenolic Content of Uncaria gambir Roxb. and Uncaria sclerophylla Roxb. Leaves. Pharmacog J. 2019;11(1):119-23. 
Indonesia. The sample was authenticated by Herbarium University of Andalas.

\section{Macroscopic and microscopic analysis}

The Leaf macroscopic morphological observation were performed using fresh leaves of Uncaria gambir and Uncaria sclerophylla. Respectively the leaves were used approx. $13-15 \mathrm{~cm}$ and $16-18 \mathrm{~cm}$ in length for U. gambir and $U$. sclerophylla ( $\mathrm{n}=3$, for each species). The leaves was observed macroscopically for shape, color, size, surface and texture characteristics. ${ }^{12}$

Microscopic analysis was performed by make thin sliced transverse section through the midrib and lamina part of the U. gambir and U. sclerophylla fresh leaf samples. ${ }^{13}$ The type of stomata was observed by make thin sliced longitudinal section above the leaf lower epidermis part. The fine sections placed on microscope glass slides and added $2 \mathrm{gtt}$ cloral hydrate solution $70 \%(\mathrm{w} / \mathrm{v})$. The glass slide then was heated for about 1 min until the color and pigment of the leaves section disappeared. One drop of glycerin added onto the fine section to help it mounted on glass slide. ${ }^{14}$ Without any staining reagent the glass slide containing the fine section were placed under microscope (ZEISS, Primo Star, Germany) for microscopic observation.

\section{Preparation of extract}

The extract was obtained using microwave assisted extraction (MAE) method at $70^{\circ} \mathrm{C}$ power 700 watt for $10 \mathrm{~min}$. Each dry powder leaf samples were extracted with 70\%ethanol and chloroform-ammonia 95: $5(\mathrm{v} / \mathrm{v})$ in a portion of 1:10 solvent $(\mathrm{w} / \mathrm{v})$. The esolution was filtered, then evaporated with rotary vacuum evaporator (Rotavapor ${ }^{\circledast}$ R-215, Buchi, Switzerland) until obtained concentrated extract. The solvent residue completely removed by vacuum oven at $37^{\circ} \mathrm{C}$ for $48 \mathrm{~h}$. This crude extract stored in refrigerator at $-20^{\circ} \mathrm{C}$ and used for phytochemical analysis and determination of total phenolic content.

\section{Preliminary phytochemical screening}

Phytochemical preliminary tests aimed to determine the presence of alkaloid and flavonoid in the ethanolic extract and chloroform extract U. gambir and U. sclerophylla leaf. The preliminary qualitative phytochemical screening were performed using Dreagendorff method for alkaloid and Shinoda test for flavonoids. ${ }^{15}$ Quninine used as a positive control for the Dragendorff test and cathethin as flavonoid positive control. Alkaloid test was performed by dissolving $100 \mathrm{mg}$ extract in $9 \mathrm{ml}$ of aquadest in test tube, then added $1 \mathrm{ml}$ of $10 \% \mathrm{HCl}$ solution. Then the mixture was heated at $70^{\circ} \mathrm{C}$ for $1 \mathrm{~min}$. To the test tube was added $1 \mathrm{ml}$ of Dragendorff solution. Shinoda test was performed by dissolving $100 \mathrm{mg}$ sample in $10 \mathrm{ml}$ of $96 \%$ ethanol.

Then added $5 \mathrm{ml}$ sample solution to the test tube. Added 4 drops of concentrated $\mathrm{HCl}$, then add $100 \mathrm{mg}$ of magnesium powder into the test tube. Pink color showed the presence of flavonoid.

\section{Thin Layer Chromatography (TLC)}

TLC analysis was performed using chromatographic precoated silica gel plates (Silica gel $60 \mathrm{~F}_{254}$, Merk, Germany) as stationary phase. Plate adjusted to size $4.5 \times 6.5 \mathrm{~cm}$. One hundred $\mu$ of extract solution and standard solution ( $1000 \mu \mathrm{l} / \mathrm{ml}$ for both solutions) were spotted onto the plate by using a $100 \mu \mathrm{l}$ volumetric capillary tube. Acetone-chloroform 8:2 $(\mathrm{v} / \mathrm{v})$ is used as mobile phase. The glass chamber saturated using mobile phase for $30 \mathrm{~min}$, then the chromatogram were developed in the saturated glass chamber containing $5 \mathrm{ml}$ of mobile phase. The plate removed after the solvent moves about $5 \mathrm{~cm}$ from the initial extract position, then the plate dried immediately. After the plate has dried the spot visualized under visible light and under UV light at $256 \mathrm{~nm}$ and $365 \mathrm{~nm}$ sequentially using UV cabinet ${ }^{16}$ (CAMAG, Switzerland). The movement from separating spot of the extract was expresed as retention factor $(R f)$. The values of $R f$ were calculated by dividing the distance traveled by the spot with the distance traveled by solvent.

\section{Determination of Total Phenolic Content (TPC)}

Total Phenolic Content of ethanolic extract and chloroform extract from $U$. gambir and U. sclerophylla leaf was determined using Folin-Ciocalteu reagent following standard procedure of Pratami et al. ${ }^{17} \mathrm{~A}$ volume of $25 \mu \mathrm{l}$ extract solution was mixed with $100 \mu \mathrm{l}$ Folin-Ciocalteu reagent (diluted $1: 4(\mathrm{v} / \mathrm{v})$ with $\left.\mathrm{ddH}_{2} \mathrm{O}\right)$ and shaken on 96-well microplate, then left to stand for $4 \mathrm{~min}$ at room temperature. Into the well added $75 \mu \mathrm{l}$ $\mathrm{Na}_{2} \mathrm{CO}_{3}$ solution (w/v), then the mixture shaken for $60 \mathrm{~s}$. Subsequently the reaction mixture was incubated for $2 \mathrm{~h}$ at room temperature. The absorbance was read at $756 \mathrm{~nm}$ using a microplate reader (VersaMax Microplate Reader, USA). The TPC calculated use the linear regression equation obtained from gallic acid standard curve $(25 \mu \mathrm{l}-400 \mu \mathrm{l})$. The equation formula was $\mathrm{y}=0.0006424 \mathrm{x}+0.156208$ with $\mathrm{r}=0.997$. The results were reported as $\mathrm{mg}$ gallic acid equivalents per gram leaf powder (mgGAE/g leaves powders).

\section{RESULTS}

\section{Macroscopic characteristics}

U. gambir (Figure 1A) has an caudate leaf apex and ovate leaf shape with a length ranging from $13-15 \mathrm{~cm}$ and the width of the leaves ranges between $6-8 \mathrm{~cm}$. U. gambir leaves have a smooth texture when touched. U. sclerophylla (Figure 1B) has an apiculate leaf apex and broadly ovate leaf shape with a length ranging between $16-18 \mathrm{~cm}$ and the width of the leaves ranging from $11-13 \mathrm{~cm}$. U. sclerophylla leaves have a rough texture when touched, with trichomes covering the entire surface of the leaf.

Both of U. gambir and U. sclerophylla have reticulated venation. The fresh leaves of U. gambir and U. sclerophylla are green colored and turn brown colored when wilted or aged. U. gambir leaves have a rigid structure and are thicker when compared to U. sclerophylla leaves which are relatively thinner and flaccid.

\section{Microscopic characteristics}

Microscopic observation of the transverse section through the midrib of $U$. gambir leaf revealed the phloem, xylem vessels, parenchyma cells (bellow the epidermis layer) and collenchyma cells (bellow the parenchyma cells) (Figure 2A). Lamina's transverse section shows a single layer of
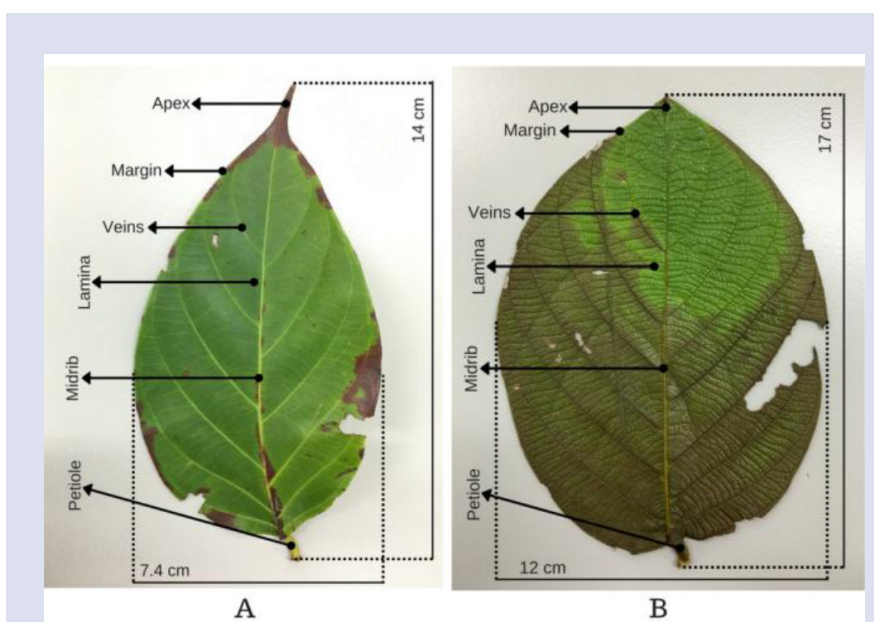

Figure 1: Macroscopic characteristics of Uncaria gambir (A) and Uncaria sclerophylla (B) leaf. 
epedermic cells, double-layers of mesophyll palisade below the upper leaf epidermis, vascular bundle between mesophyll palisade and spherical oil fragments (Figure 2B). Also can be observed the spongy mesophyll and air spaces above the lower epidermal layer. The longitudinal section revealed the stomata consisting a pair of guard cells surrounded by ordinary epidermal cells (Figure 2C). U. gambir leaf has a type of paracytic stomata.

Transvere section through the midrib of $U$. sclerophylla showed a microscopic appearance of phloem, xylem, parenchyma mesophyll,

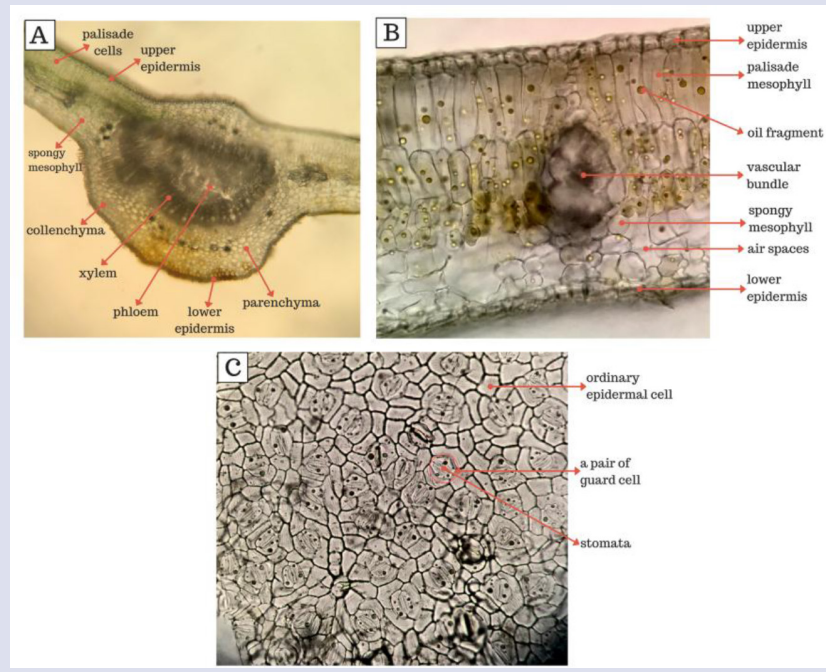

Figure 2: Transverse section showing midrib (A), lamina (B) and longitudinal section showing lower epidermis (C) of Uncaria gambir leaf.

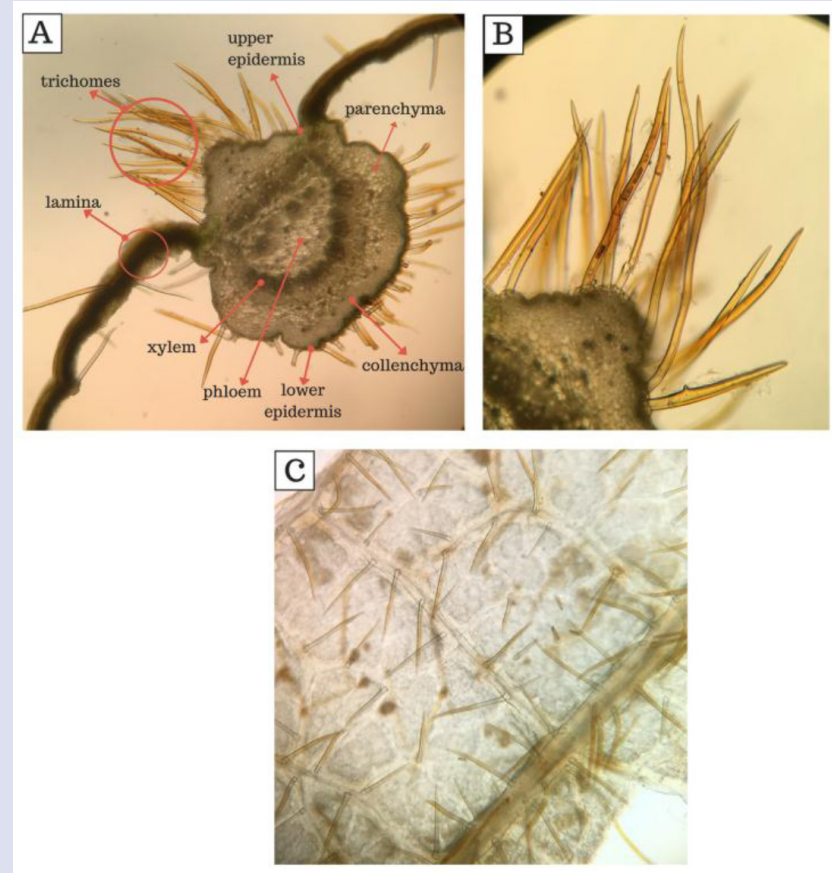

Figure 3: Transverse section showing midrib (A), trichomes (B) and longitudinal section showing lower epidermis (C) of Uncaria gambir leaf. collenchyma mesophyll, epidermic layer and trichomes (Figure 3A). $U$. sclerophylla leaf have a type of unicelullar trichomes which is shaped like a needle (Figure 3B). From the microscopic of longitudinal section can be observed the trichomes are spread throughout the leaf surface (Figure 3C). We were unable to obtain an overview of the lamina's transverse section and stomata appearance, because the slice making process was still done manually with the help of razor blade and the leaf of U. sclerophylla was too thin to make the intended sections.

\section{Phytochemical screening}

Phytochemical screening revealed that in the leaves of U. gambir and $U$. sclerophylla alkaloid and flavonoid compounds were present. The alkaloid compounds are extracted when chloroform-ammonia 95: $5(\mathrm{v} / \mathrm{v})$ are used as a solvent. Whereas the flavonoid compounds extracted when entanol $70 \%$ are used as a solvent. Phytochemical screening results shown in Table 1.

\section{TLC profiles}

Thin Layer Chromatography profile revealed the constituents contained in the etanolic and the chloroform extract of U. gambir and U. sclerophylla, each constituent in the extract gave different $R f$ values and spot color when visualized under visible light and under UV light at $256 \mathrm{~nm}$ and $365 \mathrm{~nm}$ (Figure 4). The calculation of the $R f$ value of each contituents can be shown in Table 2.

\section{Total Phenolic Contents}

The results of the determination of total phenolic content from chloroform and ethanolic extract of U. gambir and U. sclerophylla leaf shown in Table 3. The regression equation of gallic acid calibration curve was $y=0.0006424 x+0.156208$ with $r=0.997$. Total phenolic content was

Table 1: Phytochemical screening of Uncaria gambir and Uncaria sclerophylla leaf extracts.

\begin{tabular}{ccccc}
\hline $\begin{array}{c}\text { Phytochemical } \\
\text { contents }\end{array}$ & \multicolumn{2}{c}{ Chloroform extract } & \multicolumn{2}{c}{ Ethanolic extract } \\
\cline { 2 - 5 } & U. & U. & U. & U. \\
& gambir & sclerophylla & gambir & sclerophylla \\
\hline Alkaloid & + & + & - & - \\
Flavonoid & - & - & + & + \\
\hline
\end{tabular}

Note: (+): present, (-): not detected

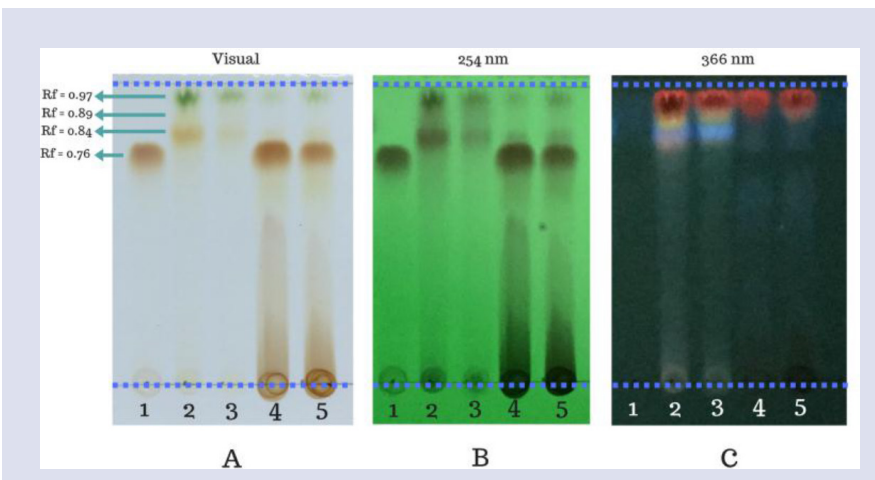

Figure 4: TLC chromatograms of U. gambir and U. schlerophylla chloroform leaf extracts respectively: 2,3 ) and $U$. gambir and $U$. schlerophylla ethanolic leaf extracts (respectively: 4,5 ) visualized under (A) visible light, (B) UV at $254 \mathrm{~nm}$ and (C) UV at $366 \mathrm{~nm}$. As a standard used cathecin solution $1000 \mu \mathrm{l} / \mathrm{ml}$ (1). Mobile phase: Acetone-chloroform 8:2 (v/v). 
Table 2: TLC profile of Uncaria gambir and Uncaria sclerophylla leaf extract.

\begin{tabular}{|c|c|c|c|c|c|c|}
\hline No. & Solution & $\begin{array}{c}R f \\
\text { values }\end{array}$ & $\begin{array}{l}\text { Visible } \\
\text { light }\end{array}$ & $\begin{array}{c}\text { UV } 254 \\
\mathrm{~nm}\end{array}$ & $\begin{array}{c}\text { UV } 366 \\
\mathrm{~nm}\end{array}$ & $\begin{array}{l}\text { Assigned } \\
\text { subtance }\end{array}$ \\
\hline 1. & $\begin{array}{l}\text { Standard } \\
\text { Catehin }\end{array}$ & 0.76 & $\begin{array}{l}\text { Dark } \\
\text { Brown }\end{array}$ & $\begin{array}{l}\text { Dark } \\
\text { Grey }\end{array}$ & - & $\begin{array}{l}\text { Cathecin } \\
\text { standard }\end{array}$ \\
\hline 2. & $\begin{array}{l}\text { Chloroform } \\
\text { extract of } U \text {. } \\
\text { gambir }\end{array}$ & $\begin{array}{l}0.76 \\
0.84 \\
0.89 \\
0.97\end{array}$ & $\begin{array}{c}- \\
\text { Light } \\
\text { Brown } \\
\text { Yeillow } \\
\text { Green }\end{array}$ & $\begin{array}{l}- \\
\text { Grey } \\
\text { Light } \\
\text { Grey } \\
\text { Grey }\end{array}$ & $\begin{array}{l}- \\
\text { Blue } \\
\text { Yellow } \\
\text { Red }\end{array}$ & $\begin{array}{l}\text { Cathecin } \\
\text { Alkaloid } 1 \\
\text { Alkaloid } 2 \\
\text { Unknown }\end{array}$ \\
\hline 3. & $\begin{array}{l}\text { Chloroform } \\
\text { extract of } U \text {. } \\
\text { sclerophylla }\end{array}$ & $\begin{array}{l}0.76 \\
0.84 \\
0.89 \\
0.97\end{array}$ & $\begin{array}{c}- \\
\text { Light } \\
\text { Brown } \\
\text { Yellow } \\
\text { Green }\end{array}$ & $\begin{array}{l}\text { - } \\
\text { Grey } \\
\text { Light } \\
\text { Grey } \\
\text { Grey }\end{array}$ & $\begin{array}{c}- \\
\text { Blue } \\
\text { Yellow } \\
\text { Red }\end{array}$ & $\begin{array}{l}\text { Cathecin } \\
\text { Alkaloid } 1 \\
\text { Alkaloid } 2 \\
\text { Unknown }\end{array}$ \\
\hline 4. & $\begin{array}{l}\text { Ethanolic } \\
\text { extract of } U \text {. } \\
\text { gambir }\end{array}$ & $\begin{array}{l}0.76 \\
0.84 \\
0.89 \\
0.97\end{array}$ & $\begin{array}{c}\text { Dark } \\
\text { Brown } \\
\text { Light } \\
\text { Brown } \\
\text { Yellow } \\
\text { Green }\end{array}$ & $\begin{array}{c}\text { Dark } \\
\text { Grey } \\
\text { Light } \\
\text { Grey } \\
\text { - } \\
\text { Gray }\end{array}$ & $\begin{array}{c}- \\
- \\
- \\
\text { Red }\end{array}$ & $\begin{array}{l}\text { Cathecin } \\
\text { Alkaloid } 1 \\
\text { Alkaloid } 2 \\
\text { Unknown }\end{array}$ \\
\hline 5. & $\begin{array}{l}\text { Ethanolic } \\
\text { extract of } U \text {. } \\
\text { sclerophylla }\end{array}$ & $\begin{array}{l}0.76 \\
0.84 \\
0.89 \\
0.97\end{array}$ & $\begin{array}{c}\text { Dark } \\
\text { Brown } \\
\text { Light } \\
\text { Brown } \\
\text { Yellow } \\
\text { Green }\end{array}$ & $\begin{array}{c}\text { Dark } \\
\text { Grey } \\
\text { Light } \\
\text { Grey } \\
\text { - } \\
\text { Grey }\end{array}$ & $\begin{array}{c}- \\
- \\
- \\
\text { Red }\end{array}$ & $\begin{array}{l}\text { Cathecin } \\
\text { Alkaloid } 1 \\
\text { Alkaloid } 2 \\
\text { Unknown }\end{array}$ \\
\hline
\end{tabular}

Note: (-) indicates at the $R f$ values no spot can be observed.

Table 3: Total phenolic content of Uncaria gambir and Uncaria sclerophylla as $\mathrm{mg}$ gallic acid equivalents per gram leaf powder.

\begin{tabular}{cc}
\hline Extract & TPC as mgGAE/g leaf powder \\
\hline Chloroform U. gambir & $0.437 \pm 0.080$ \\
Chloroform U. sclerophylla & $0.161 \pm 0.005$ \\
Ethanolic U. gambir & $7.309 \pm 0.086$ \\
Ethanolic $U$. sclerophylla & $5.734 \pm 0.019$ \\
\hline
\end{tabular}

Value are expressed as mean \pm SEM (Standard Error Measurment) of three replicates.

expressed as mg gallic acid equivalents per gram leaf powder (mgGAE / g leaf powder). The total phenolic content of U. gambir leaf higher than U. sclerophylla leaf. Ethanolic extraxtion result in a higher total phenolic content than extraction using chloroform solvent.

\section{DISCUSSION}

Uncaria genus has been widely used as medicinal ingredient, a number of studies revealed the presence of medicinal subtances in the leaf of Uncaria genus..$^{20}$ In Indonesia, it has been widely marketed pallet form of the crude extract from U. gambir. ${ }^{21}$ However, there is no sufficient information related to $U$. gambir leaf as the raw material from the crude extract pallet. In this study revealed the characteristics of macroscopy, microscopy, TLC profile and Total Phenolic Content from U. gambir and $U$. sclerophylla leaf, this information is expected to be a reference for the selection of raw materials for the production of crude extract from U. gambir and U. sclerophylla leaf.
Macroscopic from medicinal raw materials is necessary in order to avoid falsified and mistaken at the selection process of the medicinal raw materials. ${ }^{11}$ Macroscopic observation includes the observation of shape, size, color and texture can be supported by microscopic observations to obtain more specific observations such as the type of stomata and trichomes. This study revealed that $U$. gambir leaf microscopically shown spherical oil fragments, with the type of paracytic stomata. U. sclerophylla has needleshaped uniselullar type trichomes scattered throughout the leaf surface.

We use two types of solvents to extract the polyphenol and alkaloid compounds contained in Uncaria gambir and Uncaria sclerophylla leaves. Phytochemical screening was carried out to confirm the presence of the polyphenol and alkaloid compounds from the each extract yielded. Alkaloids are organic compounds containing nitrogen substituents, most of them are basic and non-polar. ${ }^{18}$ Using the principle of "like dissolved like" we suggested that alkaloids will be extracted with non-polar organic solvents such as chloroform. Ammonia which is alkaline was added to increase the solubility of alkaloids in the solvent. ${ }^{19}$ The same principle is also applied to extract flavonoids which are polyphenol groups. To extract polyphenol compounds such as flavonoids, polar solvents such as ethanol were used. It can be observed the (Table 2.) alkaloid positive present at the chloroform extract meanwhile flavonoid positive present at the ethanolic extract.

Thin layer chromatography profile examination from crude extract of $U$. gambir and U. sclerophylla aimed to make qualitative observations about the compounds contained in the crude extract. Chromatography examination was carried out using the major substituens as marker compound, in this study catechin was used as a marker. Both of U. gambir and $U$. schleropylla contain catechin $(R f=0.76)$. Catechin are present in ethanlic extract and absent in chloroform extract. It was clearly observed the alkaloids suspected spot $(R f=0.84,0.89)$, while the spots also present at the ethanolic extract but not intense. Unknown subtance $(R f=0.97)$ were present both of ethanolic and chloroform extract.

Uncaria genus has been reported rich in polyphenol compounds, a number of studies have revealed this fact., ${ }^{2,8,21}$ Determination of total phenolic content in this study aimed to provide a standard for the value of total phenolic contained in U. gambir and U. sclerophylla leaves extracts. From the results of the study, there is shown the significant differences between the total phenolic content of chloroform extract and the total phenolic content of etanolic extract. Both of chloroform extract and ethanolic extract shown that $U$. gambir leaf have a higher total phenolic content value than $U$. sclerophylla.

\section{CONCLUSION}

Characteristics macroscopy and microscopy of Uncaria gambir Roxb. and Uncaria sclerophylla Roxb. leaves in this study are suggested to be a reference in the selection process of raw materials for the manufacture of herbal medicines containing $U$. gambir and U. sclerophylla leaves. Phytochemical screening, Thin Layer Chromatography Profile and Total Phenolic Content reported were also suggested to be a brenchmark or reference for quality control of U. gambir Roxb. and U. sclerophylla Roxb. leaves extracts.

\section{ACKNOWLEDGEMENT}

The authors would like to give gratitudes to Universitas Indonesia and Ministry of Research and Higher Education for supporting this research with the grant Penelitian Dasar Unggulan Perguruan Tinggi (PDUPT) No. 266/UN2.R3.1/HKP05.00/2018.

\section{CONFLICT OF INTEREST}

The authors declare no conflict of interest . 


\section{ABBREVIATIONS}

U. gambir: Uncaria gambir; U. sclerophylla: Uncaria sclerophylla; TLC: Thin Layer Chromatoghraphy; UV: Ultraviolet; $\boldsymbol{R} f$ : Retardation factor; TPC: Total Phenolic Content; $\mathbf{d d H}_{2} \mathbf{O}$ : Double-distilled water; GAE: gallic acid equivalents.

\section{REFERENCES}

1. Ravipati A, Reddy N, Koyyalamudi S. Biologically Active Compounds from the Genus Uncaria (Rubiaceae). Studies in Natural Products Chemistry. 2014;43:381-408.

2. Anggraini T, Tai A, Yoshino T, Itani T. Antioxidative activity and catechin content of four kinds of Uncaria gambir extracts from West Sumatra, Indonesia. African Journal of Biochemistry Research. 2011;5(1):33-8.

3. Laumonier Y. The Vegetation and Physiography of Sumatra. $1^{\text {st }}$ ed. Dordrecht: Springer Netherlands. 1997;117.

4. Grosvenor P, Gothard P, McWilliam N, Supriono A, Gray D. Medicinal plants from Riau Province, Sumatra, Indonesia. Part 1: Uses. Journal of Ethnopharmacology. 1995;45(2):75-95.

5. Zhang $Q$, Zhao J, Xu J, Feng F, QuW. Medicinal uses, phytochemistry and pharmacology of the genus Uncaria. Journal of Ethnopharmacology. 2015;173:48-80.

6. Taniguchi S, Kuroda K, Doi K, Inada K, Yoshikado N, Yoneda Y, et al. Evaluation of gambir quality based on quantitative analysis of polyphenolic constituents. Yakugaku Zasshi. 2007;127(8):1291-300.

7. Kassim MJ, Hussin HH, Achmad A, Dahon NH, Suan TK, Hamdan HS. Determination of total phenol, condensed tannin and flavonoid contents and antioxidant activity of Uncaria gambir extracts. Maj Farm Indones. 2011;22:50-9.

8. Amir M, Mujeeb M, Khan A, Ashraf K, Sharma D, Aqil M. Phytochemical analysis and in vitro antioxidant activity of Uncaria gambir. International Journal of Green Pharmacy. 2012;6(1):67.

9. Yano S, Horiuchi H, Horie S, Aimi N, Sakai S, Watanabe K. Ca2+Channel Blocking Effects of Hirsutine, an Indole Alkaloid from Uncaria Genus, in the Isolated Rat Aorta. Planta Medica. 1991;57(05):403-5.

10. Zhang W, Chen C, Sim S, Kwan C. In vitro vasodilator mechanisms of the indole alkaloids rhynchophylline and isorhynchophylline, isolated from the hook of Uncaria rhynchophylla (Miquel). Naunyn-Schmiedeberg's Archives of Pharmacology. 2004;369(2):232-8

11. Kunle $\mathrm{O}$, Egharevba $H$, Ahmadu P. Standardization of herbal medicines - A review. International Journal of Biodiversity and Conservation. 2012;4(3):101-12.

12. Dave R, Nagani K, Chanda S. Pharmacognostic Studies and Physicochemical Properties of the Polyalthia longifolia var. pendula Leaf. Pharmacognosy Journal. 2010;2(13):572-6.

13. Killedar S, More H, Nadaf S. Microscopic Evaluation of Leaves of Memecylon umbellatum Burm. Advances in Agriculture. 2014;1-6.

14. Kumar D, Kumar K, Kumar S, Kumar T, Kumar A, Prakash O. Pharmacognostic evaluation of leaf and root bark of Holoptelea integrifolia Roxb. Asian Pacific Journal of Tropical Biomedicine. 2012;2(3):169-75.

15. Harborne J. Phytochemical Methods. $2^{\text {nd }}$ ed. Dordrecht: Springer Netherlands 1984:78-187.

16. Martin-Puzon J, Valle D, Rivera W. TLC profiles and antibacterial activity of Glinus oppositifolius L. Aug DC. (Molluginaceae) leaf and stem extracts against bacterial pathogens. Asian Pacific Journal of Tropical Disease. 2015;5(7):569-74.

17. Pratami D, Mun'im A, Sundowo A, Sahlan M. Phytochemical Profile and Antioxidant Activity of Propolis Ethanolic Extract from Tetragonula Bee. Pharmacognosy Journal. 2017;10(1):128-35

18. Roberts M, Wink M. Alkaloids: Biochemistry, Ecology, Medicinal Applications. $1^{\text {st }}$ ed. Boston, MA: Springer US. 1998;87-8.

19. Zhang W, Zhu D, Fan H, Liu X, Wan Q, Wu X et al. Simultaneous extraction and purification of alkaloids from Sophora flavescens Ait. by microwave-assisted aqueous two-phase extraction with ethanol/ammonia sulfate system. Separation and Purification Technology. 2015;141:113-23.

20. Heitzman M, Neto C, Winiarz E, Vaisberg A, Hammond G. Ethnobotany, Phytochemistry and Pharmacology of Uncaria (Rubiaceae). Chemlnform. 2005;36(17):5-29

21. Isnawati A, Raini M, Sampurno O, Mutiatikum D, Widowati L, Gitawati R Karakteristik tiga jenis gambir (Uncaria gambir Roxb.) dari Sumatera Barat [Characteristics of the three types of Gambier from West Sumatra]. Buletin Penelitian Kesehatan. 2012:40(4):201-8. [Bahasa Indonesia].

22. Navarro-Hoyos M, Alvarado-Corella D, Moreira-Gonzalez I, Arnaez-Serrano E Monagas-Juan M. Polyphenolic Composition and Antioxidant Activity of Aqueous and Ethanolic Extracts from Uncaria tomentosa Bark and Leaves. Antioxidants. 2018;7(5):65.

\section{GRAPHICAL ABSTRACT}

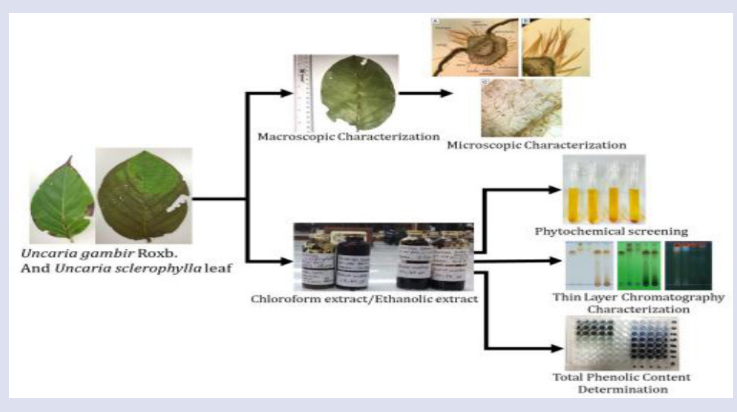

\section{SUMMARY}

- The present study provides characteristics of Uncaria gambir Roxb. and Uncaria sclerophylla Roxb. leaf as well as phytochemical screening, thin layer chromatography profile and total phenolic content as a reference for quality control of herbal medicines.

Cite this article: Sakti AS, Saputri FC, Mun'im A. Microscopic Characters, Phytochemical Screening Focus on Alkaloid and Total Phenolic Content of Uncaria gambir Roxb. and Uncaria sclerophylla Roxb. Leaves. Pharmacog J. 2019;11(1):119-23. 